\title{
EFEKTIFITAS MODEL PEMBELAJARAN KOOPERATIF TIPE SNOWBALL THROWING PADA MATERI BILANGAN KUANTUM
}

\author{
Henni Fitriani, Ayu Rahmi \\ Program studi Pendidikan Kimia, FKIP, Universitas Malikussaleh \\ Korespondensi: henni.fitriani@unimal.ac.id
}

\begin{abstract}
Abstrak: Telah dilakukan penelitian tentang efektifitas model pembelajaran kooperatif tipe Snowball Throwing pada materi bilangan kuantum. Tujuan penelitian ini adalah untuk mengetahui pengaruh model pembelajaran kooperatif tipe Snowball Throwing terhadap hasil belajar dan respon mahasiswa terhadap pembelajaran dengan menggunakan model pembelajaran kooperatif tipe Snowball throwing. Penelitian ini dilaksanakan pada semester genap tahun pelajaran 2018/2019. Subjek dalam penelitian ini adalah mahasiswa pendidikan kimia semester 4 yang mengikuti perkuliahan kimia dasar II . Instrumen yang digunakan dalam penelitian ini adalah soal-soal pilihan ganda mengenai materi bilangan kuantum dan lembar respon mahasiswa terhadap penerapan model pembelajaran kooperatif tipe Snowball Throwing. Teknik analisis data menggunakan rumus deskriptif persentase. Model pembelajaran kooperatif tipe Snowball Throwing efektif dalam meningkatkan hasil belajar mahasiswa pada materi bilangan kuantum, dengan tingkat ketuntasan hasil belajar sebesar $90,5 \%$. Respon mahasiswa terhadap pembelajaran yang menggunakan model pembelajaran kooperatif tipe Snowball Throwing juga menunjukkan respon yang positif yaitu 97,6\% mahasiswa tertarik pada pembelajaran dengan menggunakan model pembelajaran tipe Snowball Throwing tersebut.
\end{abstract}

Kata Kunci : Model Pembelajaran Kooperatif, Snowball Throwing, Bilangan Kuantum

\section{EFFECTIVENESS OF THE COOPERATIVE LEARNING OF SNOWBALL THROWING TYPE IN QUANTUM NON MATERIALS}

\begin{abstract}
Research has been conducted on the effectiveness of the Snowball Throwing type cooperative learning model on quantum number material. The purpose of this study was to determine the effect of the Snowball Throwing type cooperative learning model on learning outcomes and student responses to learning using the Snowball throwing type cooperative learning model. This research was conducted in the even semester of the 2018/2019 academic year. The subjects in this study were 4th semester chemistry education students who attended basic chemistry lectures II. The instruments used in this study are multiple choice questions regarding quantum number material and student response sheets towards the application of the Snowball Throwing type cooperative learning model. The data analysis technique uses descriptive percentages. The Snowball Throwing type cooperative learning model is effective in improving student learning outcomes in quantum number material, with a learning achievement level of 90.5\%. Student responses to learning using the Snowball Throwing type cooperative learning model also showed a positive response, namely $97.6 \%$ of students interested in learning using the Snowball Throwing type learning model.
\end{abstract}

Keywords: Cooperative Learning Model, Snowball Throwing, Quantum Numbers 


\section{PENDAHULUAN}

Pendidikan pada hakekatnya adalah suatu usaha manusia untuk meningkatkan ilmu pengetahuan yang didapat dari lembaga formal dan non formal yang didalamnya berlangsung suatu proses pendidikan. Secara umum tujuan pendidikan adalah membantu perkembangan anak didik untuk mencapai tingkat kedewasaan (Kasan, 2005). Salah satu usaha perbaikan kualitas pendidikan dilakukan melalui peningkatan kualitas sumber daya manusia. Dalam hal ini peningkatan kualitas pendidikan tidak terlepas dari kualitas proses pembelajaran. Melalui proses pembelajaran tersebut mahasiswa mendapatkan hasil belajar seperti yang diharapkan.

Pada umumnya proses kegiatan belajar mengajar baik di sekolah maupun di perguruan tinggi masih banyak yang berpusat pada guru (dosen), dimana dosen sebagai sumber informasi. Pelaksanaan pembelajaran yang berpusat pada dosen memandang pengertian mengajar sebagai kegiatan menyampaikan bahan pelajaran. Pendekatan ini amat merugikan mahasiswa karena membuat mahasiswa tidak bergairah, kegiatan belajar mengajar hanya satu arah dan hanya terjadi transfer informasi.

Meskipun demikian, tidak sedikit mahasiswa yang merasa bosan dengan belajar berkelompok saja, banyak diantara mereka yang tidak mau berdiskusi tentang apa yang sedang mereka pelajari di dalam kelompoknya, terutama pada pelajaran kimia karena mereka menganggap bahwa pelajaran kimia itu susah dan bersifat abstrak. Salah satu materi yang dianggap susah adalah materi bilangan kuantum. Untuk mengatasi masalah seperti itu, seorang dosen harus menggunakan model pembelajaran serta penyampaian yang tepat dan menyenangkan sehingga mahasiswa merasa bahwa pelajaran kimia tidak susah dan belajar kimia itu menyenangkan. Dosen sebagai pendidik memegang peranan penting baik dalam menyusun maupun melaksanakan pembelajaran. Disamping menguasai materi, seorang dosen dituntut memiliki keterampilan dalam menyampaikan materi yang diberikan dengan menggunakan berbagai model pembelajaran.

Salah satu tipe pembelajaran kooperatif yang dapat diaplikasikan dalam proses belajar mengajar adalah tipe Snowball Throwing. Pada pembelajaran kooperatif tipe Snowball Throwing siswa dituntut untuk dapat menguasai materi, melatih siswa berfikir kreatif dan belajar bertanggung jawab dalam menjalankan tugasnya (Yuliati. 2015). Model pembelajaran Snowball Throwing merupakan model pembelajaran yang menitikberatkan pada merumuskan pertanyaan yang dikemas dalam sebuah permainanyang menarik yaitu saling melemparkan bola salju (Snowball Throwing) atau kertas yang diremas dan didalamnya sudah berisi pertanyaan (Elferasari. 2017). Mahasiswa yang mendapat bola kertas lalu membuka dan menjawab pertanyaannya. Model pembelajaran kooperatif tipe Snowball Throwing ini di dalamnya terdapat unsur permainan sehingga dalam proses pembelajaran mahasiswa tidak merasa bosan, melainkan mereka merasa belajar itu menyenangkan sehingga minat belajar menjadi lebih tinggi.

Kemampuan menyimak siswa yang memiliki minat belajar tinggi lebih baik dari pada siswa yang memiliki minat belajar rendah dan terdapat interaksi antara model pembelajaran dan minat belajar dalam mempengaruhi kemampuan menyimak. kemampuan menyimak siswa yang diajar dengan model pembelajaran Snowball Throwing lebih baik (Putri, 2012) .

\section{METODE}

Penelitian ini merupakan penelitian deskriptif kualitatif yang dilaksanakan di Universitas Malikussaleh pada semester genap tahun pelajaran 2017/2018. Subjek dalam 
penelitian ini adalah mahasiswa pendidikan kimia semester 4 yang mengikuti perkuliahan kimia dasar II . Instrumen yang digunakan dalam penelitian ini adalah soal-soal pilihan ganda mengenai materi bilangan kuantum dan lembar respon mahasiswa terhadap penerapan model pembelajaran Kooperatif Tipe Snowball Throwing. Teknik analisis data menggunakan rumus deskriptif persentase untuk melihat hasil belajar dan respon mahasiswa dengan rumus

$\mathrm{P}=\frac{f}{N} \times 100 \%$

Keterangan:

P : Angka Persentase

F : Frekuensi yang dicari Persentasenya

N : Jumlah Keseluruhan Sampel yang diteliti (Sudjana:2005)

\section{HASIL DAN PEMBAHASAN}

Berdasarkan hasil penelitian yang telah dilakukan, maka dapat dilihat hasil belajar siswa pada tabel 1 .

Tabel 1. Data Hasil Belajar Mahasiswa

\begin{tabular}{|c|c|c|c|c|c|c|c|c|}
\hline No & $\begin{array}{c}\text { Kelas } \\
\text { Kontrol }\end{array}$ & Nilai & Predikat & Keterangan & $\begin{array}{c}\text { Kelas } \\
\text { Eksperimen }\end{array}$ & Nilai & Predikat & Keterangan \\
\hline 1 & $\mathrm{~N}$ & 75 & $\mathrm{~B}^{+}$ & Tuntas & PAAS & 80 & $\mathrm{~B}^{+}$ & Tuntas \\
\hline 2 & $\mathrm{~K}$ & 65 & $\mathrm{C}^{+}$ & Tuntas & NTS & 80 & $\mathrm{~B}^{+}$ & Tuntas \\
\hline 3 & B & 70 & B & Tuntas & NA & 90 & A & Tuntas \\
\hline 4 & $\mathrm{CR}$ & 75 & $\mathrm{~B}^{+}$ & Tuntas & IJ & 80 & $\mathrm{~B}^{+}$ & Tuntas \\
\hline 5 & $\mathrm{~S}$ & 45 & D & Tidak Tuntas & I & 80 & $\mathrm{~B}^{+}$ & Tuntas \\
\hline 6 & $\mathrm{ZS}$ & 80 & $\mathrm{~B}^{+}$ & Tuntas & $\mathrm{SH}$ & 75 & $\mathrm{~B}^{+}$ & Tuntas \\
\hline 7 & RM & 65 & $\mathrm{C}^{+}$ & Tuntas & $\mathrm{R}$ & 90 & A & Tuntas \\
\hline 8 & SFF & 50 & $\mathrm{D}$ & Tidak Tuntas & $\mathrm{Z}$ & 60 & $\mathrm{C}$ & Tidak Tuntas \\
\hline 9 & MY & 60 & $\mathrm{C}$ & Tidak Tuntas & MA & 90 & A & Tuntas \\
\hline 10 & LN & 45 & D & Tidak Tuntas & ER & 60 & $\mathrm{C}$ & Tidak Tuntas \\
\hline 11 & NI & 70 & $\mathrm{~B}$ & Tuntas & RAC & 75 & $\mathrm{~B}^{+}$ & Tuntas \\
\hline 12 & WS & 75 & $\mathrm{~B}^{+}$ & Tuntas & $\mathrm{KS}$ & 85 & $\mathrm{~B}^{+}$ & Tuntas \\
\hline 13 & $\mathrm{R}$ & 80 & $\mathrm{~B}^{+}$ & Tuntas & A & 90 & A & Tuntas \\
\hline 14 & NI & 60 & $\mathrm{C}$ & Tidak Tuntas & AP & 85 & $\mathrm{~B}^{+}$ & Tuntas \\
\hline 15 & $\mathrm{ZF}$ & 75 & $\mathrm{~B}^{+}$ & Tuntas & AM & 85 & $\mathrm{~B}^{+}$ & Tuntas \\
\hline 16 & SM & 45 & $\mathrm{D}$ & Tidak Tuntas & $\mathrm{A}$ & 85 & $\mathrm{~B}^{+}$ & Tuntas \\
\hline 17 & $\mathrm{~N}$ & 65 & $\mathrm{C}^{+}$ & Tuntas & $\mathrm{D}$ & 80 & $\mathrm{~B}^{+}$ & Tuntas \\
\hline 18 & US & 75 & $\mathrm{~B}^{+}$ & Tuntas & AA & 85 & $\mathrm{~B}^{+}$ & Tuntas \\
\hline 19 & $\mathrm{NH}$ & 80 & $\mathrm{~B}^{+}$ & Tuntas & MA & 75 & $\mathrm{~B}^{+}$ & Tuntas \\
\hline 20 & DF & 90 & A & Tuntas & MJ & 90 & A & Tuntas \\
\hline 21 & GNO & 40 & $\mathrm{D}$ & Tidak Tuntas & $\mathrm{AR}$ & 75 & $\mathrm{~B}^{+}$ & Tuntas \\
\hline
\end{tabular}

Berdasarkan nilai hasil belajar di atas maka diperoleh persentase ketuntasan hasil belajar mahasiswa tanpa menggunakan model kooperatif tipe Snowball Throwing (kelas kontrol) adalah sebesar $66,7 \%$. Sedangkan nilai hasil belajar mahasiswa dengan menggunakan model pembelajaran kooperatif tipe Sowball Throwing adalah sebessar 90,5\%. 
Hal ini menunjukkan bahwa hasil belajar mahasiswa dengan menggunakan model pembelajaran tipe Snowball Throwing dapat meningkatkan hasil belajar mahasiswa.

\section{Data Respon Mahasiswa}

Angket respon terhadap penerapan model pembelajar kooperatif tipe Snowball Throwing diberikan pada akhir pertemuan, yaitu setelah menyelesaikan soal post-test. Hasil analisis respon mahasiswa terhadap pembelajaran dengan menggunakan model pembelajaran kooperatif tipe Snowball Throwing pada materi Bilangan Kuantum.

Tabel 2. Hasil Data Respon Mahasiswa

\begin{tabular}{|c|c|c|c|c|c|}
\hline \multirow{2}{*}{ No } & \multirow{2}{*}{ Pertanyaan } & \multicolumn{2}{|c|}{ Frekuensi (f) } & \multicolumn{2}{|c|}{ Persentase $(\%)$} \\
\hline & & $\mathrm{Ya}$ & Tidak & $\mathrm{Ya}$ & Tidak \\
\hline 1 & $\begin{array}{l}\text { Apakah anda meyukai cara mengajar yang } \\
\text { digunakan oleh guru dalam menyampaikan } \\
\text { materi Ikatan Kimia? }\end{array}$ & 21 & 0 & 100 & 0 \\
\hline 2 & $\begin{array}{l}\text { Apakah bahasa yang digunakan oleh guru } \\
\text { dalam menyampaikan materi Bilangan } \\
\text { kuantum lebih mudah dipahami? }\end{array}$ & 20 & 1 & 95,2 & 4,8 \\
\hline 3 & $\begin{array}{l}\text { Apakah cara guru menyampaikan materi } \\
\text { menggunakan model Snowball Throwing } \\
\text { membantu anda memahami materi } \\
\text { Bilangan Kuantum? }\end{array}$ & 20 & 1 & 95,2 & 4,8 \\
\hline 4 & $\begin{array}{l}\text { Apakah belajar dengan model Snowball } \\
\text { Throwing dapar membuat anda termotivasi } \\
\text { untuk mempelajari materi Ikatan Kimia? }\end{array}$ & 21 & 0 & 100 & 0 \\
\hline 5 & $\begin{array}{l}\text { Apakah anda menyukai cara menjawab } \\
\text { pertanyaan berdasarkan bola pertanyaan } \\
\text { yang anda dapatkan dari teman? }\end{array}$ & 21 & 0 & 100 & 0 \\
\hline 6 & $\begin{array}{l}\text { Apakah anda merasa aktif dengan cara } \\
\text { mengajar yang digunakan oleh guru? }\end{array}$ & 20 & 1 & 95,2 & 4,8 \\
\hline & Rata-rata & 20,5 & 0,5 & 97,6 & 2,4 \\
\hline
\end{tabular}

Dari angket respon mahasswa yang diisi oleh 21 mahasiswa setelah mengikuti pembelajaran dengan menggunakan model pembelajaran kooperatif tipe Snowball Throwing pada materi Bilangan Kuantum. Persentase respon mahasiswa terhadap penerapan model pembelajaran kooperatif tipe Snowball Throwing dengan kriteria (Ya) $=97,6 \%$ dan (Tidak) $=2,4 \%$. Sesuai dengan kriteria persentase respon mahasiswa, di mana $61 \%-90 \%=$ Tertarik, maka persentase respon siswa termasuk kedalam kriteria tertarik. Hal ini menunjukan bahwa mahasiswa tertarik dan lebih mudah memahami materi Bilangan Kuantum dengan menggunakan model pembelajaran kooperatif tipe Snowball Throwing.

\section{PENUTUP}

Berdasarkan penelitian yang telah dilakukan, maka dapat disimpulkan bahwa model pembelajaran kooperatif tipe Snowball Throwing efektif dalam meningkatkan hasil belajar 
mahasiswa pada materi bilangan kuantum, dengan tingkat ketuntasan hasil belajar sebesar $90,5 \%$. Respon mahasiswa terhadap pembelajaran yang menggunakan model pembelajaran kooperatif tipe Snowball Throwing juga menunjukkan respon yang positif yaitu 97,6 \% mahasiswa tertarik pada pembelajaran dengan menggunakan model pembelajaran tipe Snowball Throwing tersebut.

\section{DAFTAR PUSTAKA}

Elferasari.A. 2017. Model Snowball Throwing Untuk Meningkatkan Motivasi dan Hasil Belajar Matematika Kelas XII-A SMP Kartika XII-1. UNION: Jurnal Pendidikan Matematika. Vol 5 (2)

Kasan,T. 2005. Dasar-Dasar Pendidikan. Jakarta : Study Press

Putri, N.P. Pengaruh Model Pembelajaran Snowball Throwing dan Minat Belajar Terhadap Kemampuan Menyimak (Eksperimen pada Siswa Kelas VII SMP Negeri di Boyolali).

Sudjana. 2005. Metode Statistika. Bandung: Tarsito

Yuliati. 2015. Efektifitas Penggunaan Model Kooperatif Tipe Snowball Throwing Untuk Meningkatkan Hasil Belajar Siswa pada Materi Sistem Pertidaksamaan Linear di Kelas XI-IS-2 SMA Negeri 7 Banda Aceh. Jurnal Peluang. Vol. 3 